\title{
Investment Analysis of Offshore Concessions in The Netherlands
}

\author{
Han T.J. Smit
}

Han T.J. Smit is an Assistant

Professor of Finance at Erasmus

University in Rotterdam.

\begin{abstract}
This paper contains a valuation of a complex capital project: the staged development of an oil field concession of a block on the Dutch Continental Shelf. The program is flexible in that management may change the amount of investment as uncertainty is resolved over time. The paper describes an actual "soup-to-nuts" implementation of the options methodology for exploration investments. At the core of this model is the valuation of a producing field, based on replication using Brent crude oil futures. My valuation results show that exploration investments in "speculative blocks" are more effective in resolving the inherent uncertainty, and hence are more valuable, than otherwise similar low-uncertainty blocks.
\end{abstract}

This paper describes the valuation of a complex capital project: the staged development of an oil field concession in The Netherlands. The development of a license area in the Dutch Continental Shelf consists of sequential investments in test drilling, evaluation drilling, and production capacity. The program is flexible in that management may change the amount of investment as uncertainty over the value of the project is resolved over time. For instance, when viewed in isolation, the investment for test and appraisal wells in the exploration phase, while typically yielding a low return, is actually the first link in the chain of subsequent investment decisions. The traditional net present value (NPV) method cannot capture the value of the program's flexibility in an appropriate manner.

Special thanks are extended to M.S.M.P. Bremmer of Corporate Planning and Economics of the N.A.M.; L. Cazemier of the Directoraat Generaal voor Energie, Ministry of Economic Affairs, for providing information about the government system; to J.J.J. van Trigt of Amoco Netherlands Petroleum Company; to J. Hagoort of Hagoort \& Associates B.V Petroleum Engineers; to Lenos Trigeorgis; and to the referee. The paper further benefited from the comments of M.J.J. Jonkhart, President of the National Investment Bank (NIB), concerning the use of investment analysis tools in practice. The usual disclaimer applies.
However, contingent claims analysis can be used as an analytical tool to evaluate such interdependent projects.

Real options have been identified and valued in natural resources and other investment projects. Baldwin and Clark (1993), Bjerksund and Ekern (1990), Ingersoll and Ross (1992), Kemna (1988), Majd and Pindyck (1987), Mason and Merton (1985), Myers (1987), Smit (1996), Smit and Ankum (1993), and Trigeorgis $(1986,1996)$ provide various examples of flexible investment strategies. Brennan and Schwartz (1985a, 1985b) applied real options in the valuation of natural resources, while Paddock, Siegel, and Smith $(1987,1988)$ pioneered a model for the valuation of offshore petroleum leases as a set of nested options. Dixit and Pindyck (1994) give a good description of this model in chapter 12 of their book, Investment Under Uncertainty. Kemna (1993) discusses a numerical example of the timing of the offshore investment. From a practical perspective, real-option concepts and tools have been applied in internal (pilot) studies by leading firms in the oil industry (and various other industries), such as British Petroleum, Shell, and Amoco Netherlands Petroleum Company.

This paper describes an actual "soup-to-nuts" implementation of the real-options methodology for 
exploration investments on a block on the Dutch Continental Shelf. The value of developing oil reserves is estimated by choosing a financial instrument whose probabilistic behavior is close to that of the completed project. The valuation of a producing field is at the core of this model, based on replication using Brent crude oil futures. For the valuation of exploration investments, geological and geophysical data also provide probability distributions for the amount of reserves that might be found in different "block types." The valuation results based on these data reveal the relative attractiveness of exploration investments in uncertain blocks, as well as the influence of quantity and price uncertainty on the value of exploration licenses.

The paper is organized as follows: Section I discusses the various stages in offshore development on the Dutch Continental Shelf and the government's percentage of total revenues. Section II presents the valuation model based on a dynamic replication strategy using oil futures, and the valuation results using different geological distributions. Section III provides gained insights and concluding remarks.

\section{Stages of Offshore Petroleum Development on the Dutch Continental Shelf}

For companies willing to develop reserves, there is a sequence of two stages for each of which state licenses are required. The first stage requires an exploration license. In the exploration stage, initial geological studies and geophysical surveys identify the prospects within a block. Test and appraisal drillings are done in order to prove economically exploitable reserves. If these tests are successful, a production stage follows. A production license is required for development of a field and the extraction of hydrocarbons.

\section{A. The Exploration Phase}

The decision to start the exploration phase is determined by the probability of finding exploitable reserves, oil prices, technical capabilities, and investment outlays. In this phase, management must decide if the hydrocarbon expectations of the prospects justify investment by means of exploration wells, and possibly subsequent appraisal wells. Each well requires an investment on the order of $\$ 10$ million.

The exploration license conveys an exclusive right to explore the block and carries a maximum maturity of 10 years. In rounds of exploration license applications, firms compete with each other by offering different proposals for exploitation. On the basis of seismic tests and drilling commitments, an exploration license is granted. Management must decide within six years whether to apply for a development license, or else return $50 \%$ of the block (of about $400 \mathrm{~km}^{2}$ ) to the state.

\section{B. The Production Phase}

Once economically exploitable reserves are proved, a company is entitled to request a production license, or concession, and start building production capacity. Production licenses are granted for a period of 40 years. Normally, it takes several years to build capacity before starting production, requiring investments in drilling production wells and installing production, storage, and transport facilities. Depending on the existing infrastructure, additional investments are also required for offshore facilities such as pipelines and storage, pumping, and tanker-loading facilities. As this stage requires the largest capital expenditures, this is where option value is most important. Management must determine whether and when it is optimal to invest in production facilities, given the quantity of reserves and the uncertainty of oil prices.

On the average, the state captures $50 \%$ to $80 \%$ of the total revenues of a producing field. The state's receipts consist mainly of:

1) Royalties. Royalties are computed according to a percentage of the revenues from oil and gas produced under the license.

2) State participation. An arrangement exists in which the state and the oil companies are jointly involved in the recovery and sale of oil and natural gas. For the Dutch government, Energy Control Netherlands (EBN) is entitled to take a $50 \%$ participation in the exploitation of oil and gas discoveries. As compensation, EBN will refund 50\% (the participation share) of exploration costs and investments incurred in the past.

3) State profit share. In addition to the state participation, there is a state profit share. To support exploitation of marginal reserves, fields with low operating costs per barrel are taxed more heavily than fields with high operating costs per barrel.

4) Dutch corporate income tax at a rate of $35 \%$.

At the production phase of the investment program, uncertainty regarding the quantity of reserves is resolved, and the production profile for the field's useful life is determined.

\section{Nested Options and Resolved Uncertainty}

The sequence of project stages can also be viewed as a set of nested call options. The several contingent decisions are illustrated in the decision tree shown in Figure 1. As shown in Figure 1, management has the following 


\section{Figure 1. Decision Tree for the Offshore Project}

Management has the following contingent decisions $(\square)$ or options: the option to start test drilling, to invest in appraisal wells, to invest in development, and to abandon. At the same time, price and quantity uncertainty (O) evolves over the life of the project.

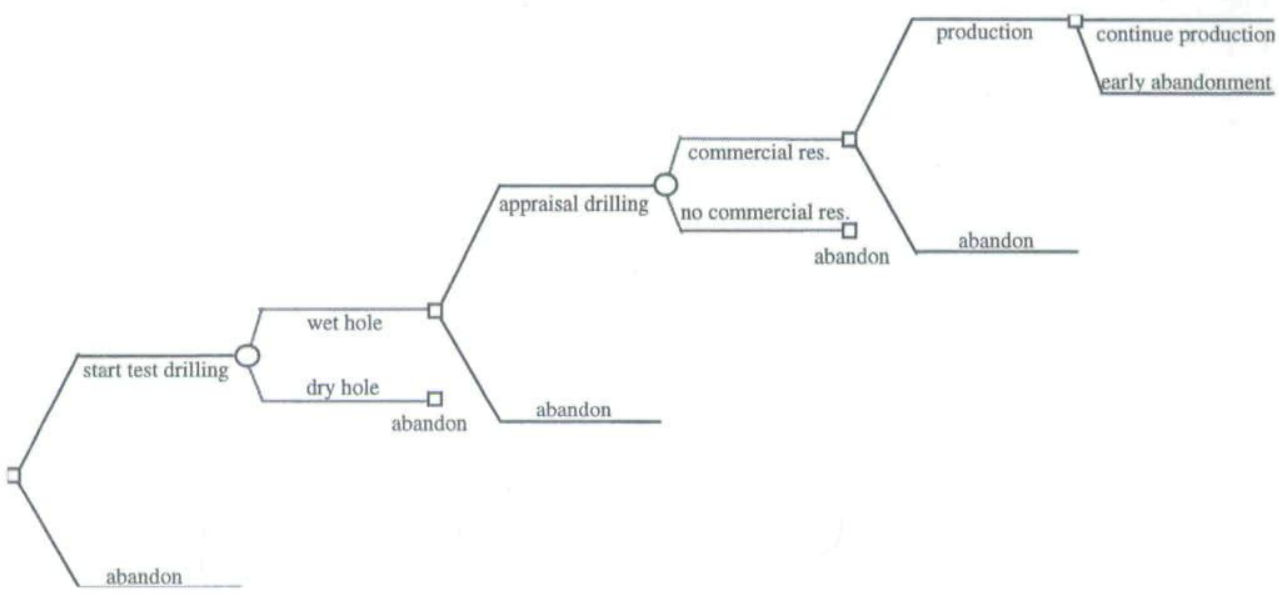

contingent decisions or options:

The Option to Start Test Drilling-Geological and geophysical studies help in identifying prospective locations for drilling. Based on these prospects, management can apply for an exploration license and start test drilling.

The Option to Invest in Appraisal Wells-If oil is found after test drilling, further drilling can ascertain whether the reserves are large enough and hence suitable for commercial production.

The Option to Invest in Development-Following the exploration phase and having determined the amount of exploitable reserves in a field, it has to be decided whether to exploit the field and start development or else to abandon operations.

The Abandonment Option-At the end of the project's life, management must incur certain abandonment costs. Total expenses for dismantling may require more than \$18 million. However, management has the option of shutting down production early to avoid incurring additional fixed costs. There is no option to temporarily shut down (mothballing) in the North Sea, since there is such rapid, extensive deterioration of pipelines and facilities. Final abandonment of production will take place when the value of continue and abandon later declines under the value of immediate abandonment.

At the same time, different types of uncertainty or risk are resolved in different stages (shown in Figure 1).

Uncertainty in the Quantity of the Reserves-Test drilling for exploration wells maximizes information on the geological section and resolves the uncertainty with respect to the presence of hydrocarbons. Evaluation drilling by means of additional appraisal wells ascertains the size of the accumulation of reserves in the well.

Uncertainty in Oil Prices-After the uncertainty of the quantity of reserves is (partly) resolved, the risk of the project is dominated by changes in oil prices. The quantity of reserves found in combination with the range of future oil prices determine whether the field is suitable for commercial exploitation.

The uncertainty or risk of the project evolves over the life of the project, changing after each branch. The initial decision to invest in test drillings is reached by first looking at the future consequences. Naturally, better informed decisions can be made after uncertainty gets resolved over time. For example, the decision to invest in production facilities is contingent on the quantity of reserves found during the exploration phase and the oil price at that time. The idea is to begin with each potential quantity of reserves and oil prices at the terminal nodes in the decision tree and determine the optimal decision to make at each of these points. This means that we start solving at the right side of a more complex and detailed tree, valuing a producing field, and then working backward in time to the left to value the exploration phase. As is well known, the standard NPV rule has shortcomings in capturing the flexibility value and changes in risk structure.

\section{Asset Valuation Based on Replication in Financial Markets}

In order to make the model accessible as a practical aid to corporate planners, appropriate, user-friendly 
software must be developed with simulation capabilities that can handle multiple options. For this particular model, I used a Microsoft Excel spreadsheet. This section provides the model and valuation of exploration investments. The valuation of a producing field at the core of this model is based on replication using Brent crude oil futures. The values of producing fields with different reserves and a geological probability distribution of the potential reserves provide the basis for the exploration investment decisions.

\section{A. Valuation of a Producing Field}

Firms presumably create value by investing in those projects for which the market value of cash inflows exceeds the required investment outlay. Therefore, the process of real-asset valuation attempts to determine what a project would be worth if it were to be traded in the financial markets. Similarly, the real-option valuation of a producing field is based on designing a portfolio in the financial market with the same risk characteristics as the project. For example, consider the position of an oil company that owns a producing field. The corporation's position is long in oil. That company could offset this position and realize the value of the field immediately by selling short an oil futures portfolio that matches the field's production over time.

\section{B. Estimating Brent Crude Futures Prices}

At the International Petroleum Exchange (IPE) in London (and other futures markets), Brent crude oil futures transactions with expiration dates longer than six months are not available. To value the field, I therefore use "hypothetical long-term futures" to offset the long-term position of a field. What would be the price of these long-term contracts if they were to be traded? In arbitrage-free markets, the futures price would equal the current spot price of Brent crude oil plus the interest accrued until maturity of the contract. ${ }^{1}$

Actually, the price of the hypothetical oil futures contract cannot be exact. Traders have additional storage costs or production benefits of physically holding oil, compared to holding a futures contract. For example, to avoid shortages in various industries, oil inventories can conveniently be held for long periods. The benefits and costs of having a physical

\footnotetext{
${ }^{1}$ Suppose that this relation does not hold and, for example, the price of an oil futures contract with a ten-year maturity is higher. If this happens, a "cash-and-carry arbitrage" opportunity is available if traders short this futures contract and simultaneously buy the Brent crude. Ten years later, the oil is delivered to cover the short position in the long-term futures contract for more than the current spot price and ten years of accrued interest. Hence, traders would not be willing to serve this "free lunch" for the company by selling this overpriced futures contract. Likewise, the corporation would not be willing to sell the futures contract for a lower price.
}

inventory of oil instead of a futures contract are referred to collectively as the implied convenience yield in the futures market. In the spreadsheet, Equation (1) estimates the hypothetical futures price from the available Brent crude spot price, increased at the risk-free rate of interest less an (estimated) convenience yield.

$$
\mathrm{F}_{\mathrm{t}}=\mathrm{S}_{\mathrm{t}}\left(1+\mathrm{r}_{\mathrm{t}}-\delta_{\mathrm{t}}\right)^{(\mathrm{T}-\mathrm{t})}
$$

The inverted relationship becomes:

$$
\delta_{t}=\left(1+r_{t}\right)-\sqrt[(T-1)]{\left(\frac{F_{t}}{S_{t}}\right)}
$$

where $\delta_{t}$ is the convenience yield, T-t is the time to maturity of the contract, and $\mathrm{r}$ is the risk-free interest rate. In this cash-and-carry valuation, the hypothetical futures prices, $\mathrm{F}$, cannot be exceedingly high relative to the spot price, $S$.

For estimating the long-term futures price, $\mathrm{F}_{t}$, we need to input the convenience yield. The current implied convenience yield can be estimated by inverting the relationship between three-month Brent crude futures and the current spot price given by Equation (2). Figure 2 shows the time series (monthly data) for implied convenience yields estimated in this fashion for a moving window from January 1991 to December 1993. The short-term (three-month) convenience yield is expressed on a yearly basis in this graph. This convenience yield is not deterministic so it is hard to estimate. In an extreme situation, the futures price can be so far below "full carry" that the spot price can exceed the futures price. Then the market is in backwardation, expressing the high demand for immediate oil (as, for example, in January 1991 at the end of the Gulf War). The average convenience yield in this period equals $7 \%$.

For simplicity, I estimated the long-term futures prices (up to 20 years) using a constant $7 \%$ long-term convenience yield and a $7 \%$ long-term interest rate. The oil price, $S_{0}$ (as of March 4, 1994), was \$14 per barrel.

\section{Estimating the Uncertainty in Oil Prices}

In addition to estimating the value from directoperating-cash inflows, estimating uncertainty is essential to determine the flexibility value of an operating field. After uncertainty in quantity is resolved in the exploration phase, uncertainty regarding the operating field is dominated by oil price uncertainty. How would one make a good estimate of the volatility for the next 20 years of the field's development? In principle, there are two methods. One prospective method is based on calculating the implied volatility resulting from the market prices of call options on Brent crude oil futures traded on the 
Figure 2. The Convenience Yield of Three-Month Brent Crude Futures and the Three-Month Certificate of Deposit (COD) Interest Rate, During the Period 1/1/91 Until 12/1/93

The time series (monthly data) for implied convenience yields estimated for a moving window from January 1991 to December 1993. The short-term (three-month) convenience yield is expressed on a yearly basis in this graph.

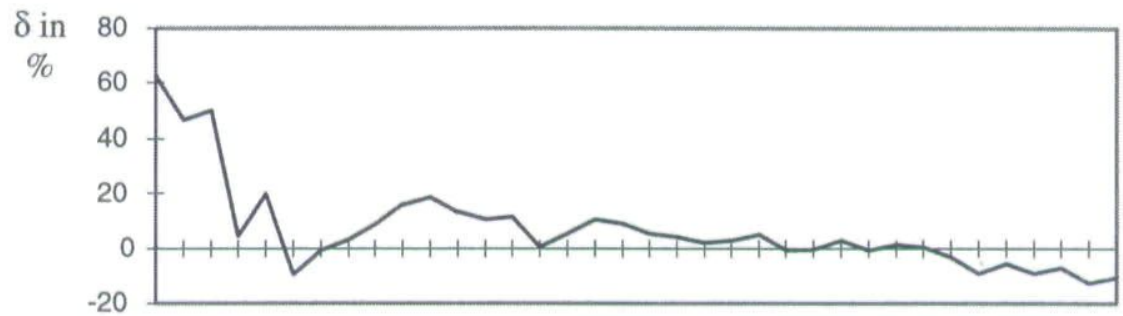

International Petroleum Exchange. Unfortunately, long-term options contracts are not traded so the method loses its relevance. A second method is to calculate the standard deviation from the time series of spot-market oil prices and use this historical standard deviation as an estimate for the volatility of Brent crude futures prices. Figure 3 illustrates the weekly Brent crude oil price per barrel (in dollars) from $2 / 19 / 88$ to $1 / 7 / 94$. During this period, the increase in price is a result of the uncertain market supply of crude oil during the Gulf War.

Table 1 presents the yearly standard deviation of Brent crude oil returns estimated in different sample periods using weekly data. The standard deviations of the different time series vary from $41.17 \%$ in 1988 to $17.38 \%$ in 1992 . To allow for this estimation problem and its influence on the value of the flexible investment program, I later provide a sensitivity analysis on volatility. In the valuation that follows, the base-case standard deviation is set at $22 \%$, based on the low volatility of the time series in 1992 and 1993. To reflect the sensitivity to this parameter, I also valued the field using $15 \%$ and $30 \%$ standard deviations.

\section{Reserve Valuation with Continuous Production}

I consider first the valuation of a hypothetical producing field without taking into consideration any of the options described earlier. At this phase of the investment program, uncertainty regarding the quantity of reserves is resolved and the production profile is expected to follow a fixed pattern over the field's useful life. For this producing field, the oil price dynamics result in a closely related, dynamic movement of the operating-cash inflow.
Future-oil prices and the linked-gas prices are assumed to follow a lognormal process, which is modeled in discrete time by a multiplicative binomial process (see Cox, Ross, and Rubinstein, 1979). In each subperiod of one year, prices may increase by a multiplicative factor $\mathrm{u}$, or decline by a factor $\mathrm{d}$. The yearly base-case standard deviation in returns of $22 \%$ per year implies a $25 \%$ increase $(u \approx 1.25)$ or a $20 \%$ decline $(d \approx 0.80)$ per year in spot and future prices. In the spreadsheet, Equations (3), (4), and (5) are used to estimate the series of future oil prices over the 32-year life of the total project (exploration and production phase). In the following valuation process, the hedging (risk-neutral) probability, p, is based on a dynamic replication strategy using futures in Brent crude oil partly financed with a risk-free loan. Note that the risk-neutral probability is adjusted for the convenience yield, $\delta$.

$$
\begin{aligned}
& \mathrm{u}=\mathrm{e}^{\sigma}, \mathrm{d}=\frac{1}{\mathrm{u}} \\
& \mathrm{uS} \mathrm{S}_{\mathrm{t}}=\mathrm{S}_{\mathrm{t}+1}^{+} \\
& \mathrm{d} \mathrm{S}_{\mathrm{t}}=\mathrm{S}_{\mathrm{t}+1}^{-} \\
& \mathrm{p}=\frac{(1+\mathrm{r}-\delta) \mathrm{S}_{\mathrm{t}}-\mathrm{S}_{\mathrm{t}+1}^{-}}{\left(\mathrm{S}_{\mathrm{t}+1}^{+}-\mathrm{S}_{\mathrm{t}+1}^{-}\right)}
\end{aligned}
$$

where $\mathrm{p}$ is the hedging (risk-neutral) probability, and $\mathrm{r}$ is the risk-free interest rate.

Following a fixed-production profile, the uncertainty of the yearly cash flow of the field is reflected in the prices, not in the quantity produced, of Brent crude oil. For each state (potential) oil price, S, the net operating cash inflow for this field equals the reserves produced yearly, $\mathrm{Q}_{\mathrm{t}}$, times the current spot price, $\mathrm{S}_{\mathrm{t}}$, minus the operating costs, the state participation, 


\section{Figure 3. Brent Crude Physical Oil Price in US Dollars per Barrel}

Weekly Brent crude physical oil price FOB in US\$ per barrel from $2 / 19 / 88$ to $1 / 7 / 94$. During this period, the increase in price is a result of the uncertain market supply of crude oil during the Gulf War.

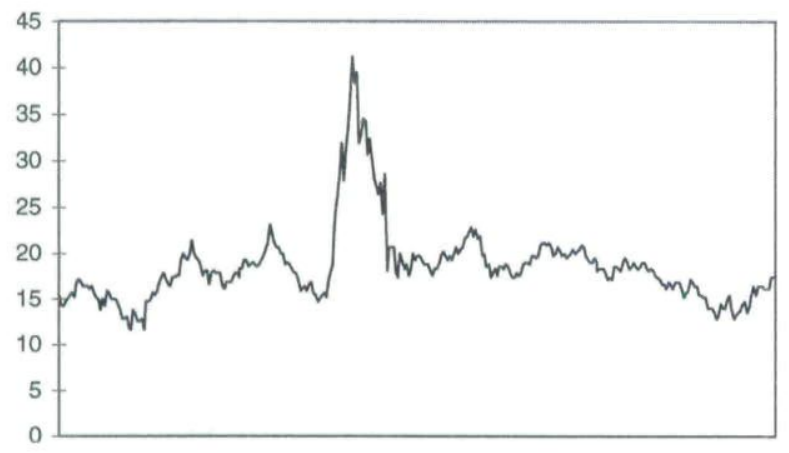

royalties, profit share, and corporate taxes.

In this fashion, an oil-price-related movement results in a series of potential operating cash flows. The reserve valuation procedure for the operating field works recursively, starting at the terminal nodes of the tree and working backward in time to the beginning of the production phase. In the final production period (at $\mathrm{t}=32$ ), the state project value equals the operating cash flow $\mathrm{CF}_{\mathrm{s}}$. For each state oil price $\mathrm{S}$, Equation (7) is used to sum the state project cash inflows when stepping backward in time.

$$
\mathrm{V}_{\mathrm{t}}=\mathrm{CF}_{\mathrm{t}}+\frac{\mathrm{pV}_{\mathrm{t}+1}^{+}+(1-\mathrm{p}) \mathrm{V}_{\mathrm{t}+1}^{-}}{1+\mathrm{r}}
$$

where $\mathrm{V}$ is the project value under continuous production.

\section{E. The Option to Abandon Operations Early}

Consider again the hypothetical producing field, but with an additional twist. At the end of the economic life of the project, management is required to pay for dismantling the platform and other production facilities. Total expenses for thus restoring the environment may require in our case $\$ 18$ million. ${ }^{2}$ Furthermore, management has the option of shutting down production early if the remaining operating value becomes negative and exceeds the abandonment costs. This flexibility is

\footnotetext{
${ }^{2} \mathrm{~A}$ tax relief has already been granted by means of deduction.
}

\section{Table 1. Yearly Standard Deviation of Oil Returns Calculated on Different Subsets of the Data}

The yearly standard deviation of Brent crude oil returns are estimated in different sample periods using weekly data. The standard deviations of the different time series vary from $41.17 \%$ in 1988 to $17.38 \%$ in 1992 . To allow for this estimation problem and its influence on the value of the flexible investment program, we later perform a sensitivity analysis on volatility.

$\begin{array}{ll}\begin{array}{l}\text { Std. Dev. Over Total Period } \\ \text { (Including Gulf War) }\end{array} & 41.40 \% \\ \begin{array}{l}\text { Std. Dev. Over Total Period } \\ \text { (Excluding Gulf War) }\end{array} & 32.11 \% \\ \text { Std. Dev. - } 1988 & 41.17 \% \\ \text { Std. Dev. - } 1989 & 26.56 \% \\ \text { Std. Dev. - } 1990 & 27.00 \% \\ \text { Std. Dev. - } 1991 & 39.41 \% \\ \text { Std. Dev. - } 1992 & 17.38 \% \\ \text { Std. Dev. - } 1993 & 23.34 \%\end{array}$

particularly valuable for small undeveloped reserves and during periods of low oil prices.

For the valuation of this particular field, I refer to the binomial valuation tree resulting from the recursive valuation procedure for the operating field without any of the options. Equation (8) subtracts the costs at the end of the project's life for restoring the environment. When stepping back again in the tree using Equation (9), the adjusted state project value, $\mathrm{V}^{*}$, equals the maximum of the operating value $\mathrm{V}$ and the nonoperating value from immediate abandonment (equal to the breakdown costs $\mathrm{A}$, with $\mathrm{A}<0$ ).

At the end of the life of the well:

$$
\mathrm{V}_{\mathrm{T}}^{*}=\mathrm{A} \text { for } \mathrm{Q}_{\mathrm{T}}=0
$$

For early abandonment:

$$
\mathrm{V}^{*}=\operatorname{MAX}\left[\mathrm{A}, \frac{\mathrm{pV}^{+}+(1-\mathrm{p}) \mathrm{V}^{-}}{1+\mathrm{r}}\right] \text { for } \mathrm{Q}_{\mathrm{t}}>0
$$

where $\mathrm{V}^{*}=$ value of the reserves including the option to abandon early, and $\mathrm{A}=$ abandonment costs (assumed to be $15 \%$ of the investment outlay in production facilities).

\section{F. The Option to Invest in Development}

Now I consider the valuation of a similar field in an earlier phase. The field is still undeveloped, and management must decide if and when to invest millions 
of dollars to bring it into production. To commence production, the corporation must invest in the installation of offshore platforms, including pipelines and storage, pumping, and tanker-loading facilities. In this case, EBN's state participation and the company must spend $\$ 120$ million for small reserves, while investing $\$ 130$ million for a higher production field ( $\mathrm{Q}>60$ million barrels). Since this decision stage requires the largest outlay, the option value is very important. When is it optimal (if at all) to invest in production facilities, given the quantity of reserves, in light of the uncertainty in oil prices?

An undeveloped field in this stage can be viewed as similar to a call option. The underlying asset is the value of a completed, operating field (including the option to abandon). The investment opportunity value, NPV*, equals:

$$
\mathrm{NPV}^{*}=\mathrm{MAX}\left[\mathrm{V}^{*}-\mathrm{I}, \frac{\mathrm{pNPV}^{+}+(1-\mathrm{p}) \mathrm{NPV}^{-}}{1+\mathrm{r}}, 0\right]
$$

where $\mathrm{NPV}^{*}$ is the net present value including the value of flexibility, and $\mathrm{I}$ is the investment outlay in development. In Equation (10), the present value of the investment outlay in production facilities, I, is equivalent to the exercise price. If in time the operating field value exceeds the investment outlay, management would invest and the undeveloped net field value equals NPV ${ }^{*}=\mathrm{V}^{*}-\mathrm{I}$. However, due to uncertainty in oil prices, the NPV may turn out to be negative. In this case, however, management may decide not to invest and the net value would be zero.

Besides the wait-and-see advantage, deferment has certain disadvantages. For example, management may receive the net operating cash inflow later on. Again, the question is: what would this call option on the Brent crude futures position be worth if it were traded in a financial market?

Table 2 illustrates the valuation results for ten undeveloped fields, ranging from proved reserves of ten million barrels to an undeveloped field of 100 million barrels. In particular, for small (low NPV*) fields the option characteristics of development and abandonment are important. Because of the option characteristics, the greater the volatility of oil prices, the larger the value of the reserves.

\section{G. Valuing Exploration Drillings}

Next consider the valuations that take place in the exploration phase. During the exploration phase, the geological distribution of the reserve quantity is updated twice: test drillings indicate the presence of reserves, and appraisal drillings provide additional information about the quantity of reserves. The value of an appraisal drilling is made only after a strike. Figure 4 presents an example of the two-step valuation procedure for a block with a large probability of finding a small quantity of reserves. Starting from the values of the producing fields shown on the right, the value of appraisal drilling is calculated by using the quantity distribution conditional on a strike. The procedure continues by working backward to the value of exploration drilling, using the probability of a strike.

First consider the valuation of an undeveloped field where the corporation has just proved the existence of oil and gas in the license area. For exploration drillings, production facilities could be leased from specialized drilling contractors (e.g., Schlumberger or Ned drill) at some daily rate. Geological expectations must justify a further investment of \$10 million in appraisal wells in order to estimate the quantities more exactly.

The uncertainty regarding the quantity of oil or gas reserves is unrelated to the overall economy, and is therefore nonsystematic. Because this uncertainty can be fully diversified, we can estimate the value of an undeveloped field using both the risk-free rate and the actual probabilities of the distribution. In order to estimate the value of a new well, using Equation (11), the quantities of reserves and the corresponding values of the producing fields, including options, shown in Table 2 represent the potential values at the end of the exploration phase. First, these (producing and nonproducing) NPVs* are multiplied by the actual probability of finding the corresponding quantity, conditional on exploration drilling resulting in a strike. Second, the expected value is discounted back for two years of appraisal drilling, using the risk-free interest rate. Finally, the expected value of the well is determined by summing the expected discounted values:

$$
\mathrm{V}^{\text {Strike }}=\frac{\sum\{\mathrm{P}(\mathrm{Q})=\mathrm{x} \mid \mathrm{Q}>0\} \mathrm{NPV}_{\mathrm{Q}}^{*}}{(1+\mathrm{r})^{\mathrm{T}-\mathrm{t}}}
$$

where $\{\mathrm{P}(\mathrm{Q})=\mathrm{x} \mid \mathrm{Q}>0\}$ is the probability conditional on quantity $\mathrm{Q}$ after a strike; $\mathrm{V}^{\text {Strike }}$ is the value of the program after a strike; and $\mathrm{T}$ - $\mathrm{t}$ is the two-year time lag between drilling appraisal wells and production.

For example, in Table 2, the estimated value of a 40 million-barrel well is equal to $\$ 19.653$ million (Quantity $=40, \sigma=22 \%$ ). In Figure 4, the probability of finding a quantity of 40 million barrels is $14 \%$ and the probability of finding oil is $96 \%$, and the conditional probability of finding 40 million barrels (after a strike) equals $14 \% / 96 \%$. The expected value of finding this quantity is $0.14 / 0.96(19.653)=\$ 2.866$ million, and the present value of a 40 million-barrell well equals $\$ 2.866$ million $/(1.07)^{2}=\$ 2.503$ million. ${ }^{3}$ The expected value of the field after a strike is calculated by summing the expectation of the present values of these wells over the

${ }^{3}$ See also Panel A, Table 3 at Quantity $=40, \sigma=22 \%$. 


\section{Table 2. Reserve Valuation (NPV*) at Different Quantities of Proven Reserves (in Millions of Dollars)}

Reserve valuation results for ten undeveloped fields, ranging from proved reserves of ten million barrels to an undeveloped field of 100 million barrels, for $\sigma=15 \%, 22 \%$, and $30 \%$. The investment outlay for development is estimated at $\$ 120$ million for $\mathrm{Q} \leq 60$ million barrels and at $\$ 130$ million for $\mathrm{Q}>60$ million barrels. The cost for dismantling facilities is assumed to be $15 \%$ of the investment outlay. The long-term futures prices are estimated using a constant $7 \%$ long-term convenience yield and a 7\% long-term interest rate. The oil price as of March 4, 1994 was \$14 per barrel.

\begin{tabular}{|c|c|c|c|c|c|c|c|c|c|c|}
\hline \multicolumn{11}{|l|}{ Million } \\
\hline Barrels & 10 & 20 & 30 & 40 & 50 & 60 & 70 & 80 & 90 & 100 \\
\hline$\sigma=15 \%$ & 0.000 & 1.261 & 7.973 & 18.326 & 25.458 & 34.984 & 40.664 & 46.690 & 55.847 & 68.972 \\
\hline$\sigma=22 \%$ & 0.151 & 2.595 & 10.762 & 19.653 & 27.149 & 36.630 & 42.239 & 48.156 & 57.270 & 70.276 \\
\hline$\sigma=30 \%$ & 0.476 & 4.406 & 14.183 & 23.438 & 29.460 & 39.557 & 45.336 & 51.740 & 61.404 & 74.545 \\
\hline
\end{tabular}

\section{Figure 4. Decision Tree for a Sure-Small-Quantity-Type Block}

This figure presents the valuations that take place in the exploration phase. Starting from the values of the producing fields shown on the right, the value of appraisal drilling is calculated by using the quantity distribution conditional on a strike. The procedure continues by working backward to the value of exploration drilling, using the probability of a strike. Even though the probability of finding oil and gas reserves for this type of block is high, it is not attractive to commerce exploration drilling.

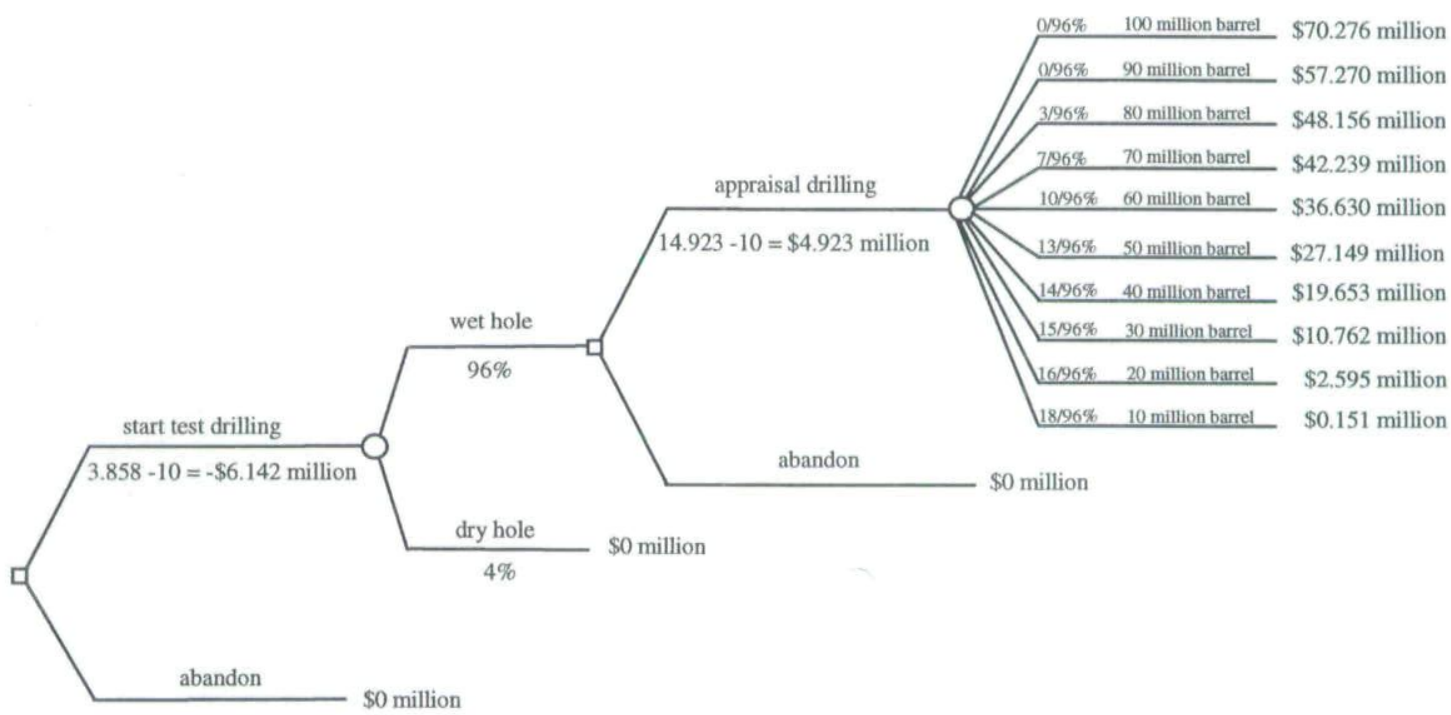

total geological distribution, taking discrete steps of 10 million barrels (e.g., 10, $20 \ldots 100$ ). This results in a $\$ 14.923$ million value for this block. The appraisal drillings require an investment of $\$ 10$ million, hence management would continue to drill for appraisal wells ( $\$ 14.923$ million - \$10 million > \$0 million).

Finally, in the second step of the valuation procedure, Equation (12) estimates the value of the option to start exploration drilling:

$$
V^{\exp }=\frac{P(Q=0)(0)+P(Q>0)\left\{\text { MAX }\left(V^{\text {Strike }}-I^{\text {ap }}, 0\right)\right\}}{(1+r)^{T-t}}
$$

where $V^{\exp }$ is the value of the exploration phase; $\mathrm{I}^{\text {ap }}$ is the investment outlay of $\$ 10$ million for appraisal drilling; $\mathrm{T}-\mathrm{t}$ is the three-year time lag between exploration drilling and drilling appraisal wells.

The NPV after the required appraisal drillings equals $\$ 14.923$ million - 10 million $=4.923$ million; the cumulative probability of finding oil is $96 \%$; therefore, the option value to invest in exploration drillings equals 0.96 (14.923 - 10) $/ 1.07^{3}=\$ 3.858$ million. Estimating the outlay for exploration drillings at $\$ 10$ million, the NPV of exploration drillings turns out to be negative: $\$ 3.858$ million - $\$ 10$ million $=-\$ 6.142$ million. Even though the probability of finding oil is high, it is not attractive to start exploration drilling in this sure-small-quantity-type block.

\section{H. Expectation Curves}

Extensive geological and geographical research has been conducted in the North Sea. To gain an 


\section{Figure 5. Cumulative Distribution of the Reserves}

The expectation curves for three hypothetical block types, which are representative of blocks in the Continental Shelf. The vertical axis represents the cumulative probability of finding the corresponding quantity of reserves. All three distributions have the same expected quantity of reserves (equal to 35 million barrels).

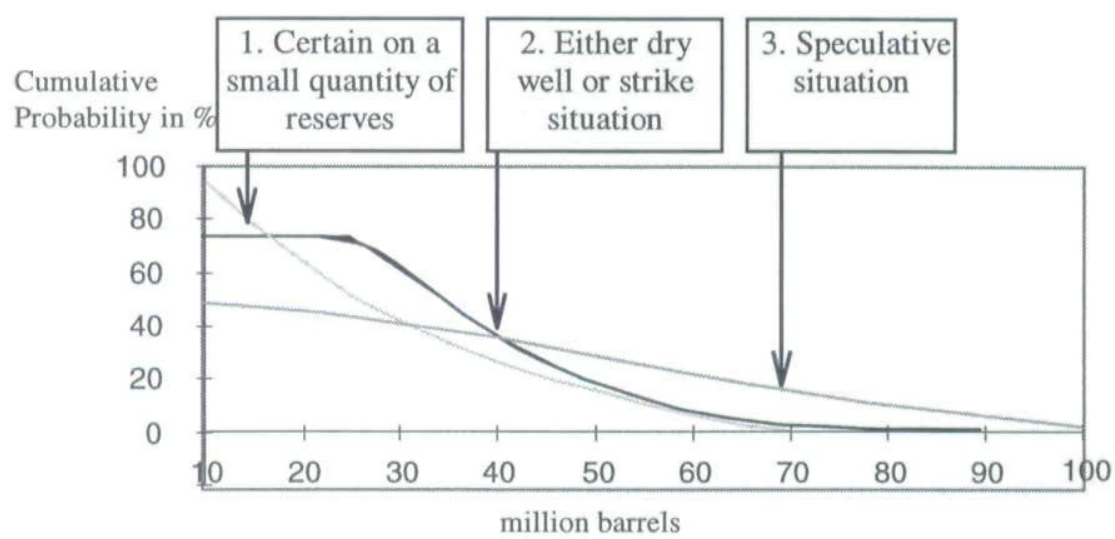

insight into potential reserves and to find the best locations for drilling, the Rijks Geologische Dienst (RGD), EBN, and the large oil corporations map the soil structure of the blocks.

How does geological uncertainty influence the value of a block? For this case study, Figure 5 describes the cumulative distribution of reserves for three hypothetical block types (expectation curves obtained from Shell, 1988), which are representative of blocks in the Continental Shelf. The vertical axis represents the cumulative probability of finding the corresponding quantity of reserves. For example, the either-dry-wellor-strike block has a $55 \%$ cumulative probability of finding 40 million barrels or more. This cumulative probability is calculated by starting at a quantity of 100 million barrels and summing the probabilities, taking discrete steps of 10 million barrels. All three distributions have the same expected quantity of reserves (equal to 35 million barrels).

1) The first block has a large probability of finding an exploitable quantity of reserves $(96 \%$ cumulative probability). For example, this might be the case if the block is adjacent to blocks with small proven reserves.

2) The second type of block has a $25 \%$ chance of finding either a dry well or a $75 \%$ cumulative probability of finding a commercially exploitable quantity of reserves.

3) The speculative third block has a $56 \%$ cumulative probability of finding oil or gas. If a well is found, there still remains great uncertainty regarding the quantity of the reserves.

Table 3 provides the expected values of the other blocks using the values of the completed field shown in Table 2, for $\sigma=15 \%, 22 \%$, and $30 \%$. Panel A in Table 3 refers to the sure-small-quantity-type block, Panel B considers the either-dry-well-or-strike-type block, and Panel C considers the speculative-type block.

It can be confirmed from Table 3 that the volatility of oil prices has a positive influence on the value of the investment program. But more interesting is that exploration investments are more valuable in a speculative-type block than in a sure-small-quantitytype block. The base-case NPV of the sure-smallquantity-type block equals $-\$ 6.124$ million. The NPV of the either-dry-well-or-strike-type block equals $-\$ 3.001$ million, and the NPV of the speculative-type block equals $\$ 0.225$ million. The exploration investments in the speculative block are more effective in resolving the uncertainty than the exploration investments in a certainty situation because there is more risk involved. Therefore, management's flexibility to change the implicit investment scenario will be more valuable for the more uncertain blocks.

Even if current oil prices were to rise (to \$20), the speculative block would continue to offer the highest NPV (\$12.635 million). However, there is a non-linearity between the value of blocks and oil price changes. At higher oil prices, intermediate reserves and then small reserves would become commercially attractive for development. As a result, the sure-small-quantity block (\$6.351 million) and the either-dry-well-or-strike block ( $\$ 10.290$ million) become relatively more valuable as oil prices rise. 


\section{Table 3. Valuation Results (in Millions of Dollars)}

Valuation of exploration investments for three block types, for $\sigma=15 \%, 22 \%$, and 30\%. Panel A refers to the sure-smallquantity-type block, Panel B considers the either-dry-well-or-strike-type block, and Panel C refers to the speculativetype block. The expected value of the exploration investment is calculated by taking the expectation of the values of a completed field (shown in Table 2) over the total geological expectation curve (shown in Figure 5). The valuation results show that exploration investments for speculative blocks are more effective in resolving the inherent uncertainty, and hence are more valuable, than for otherwise similar low-uncertainty blocks.

\begin{tabular}{|c|c|c|c|c|c|}
\hline \multicolumn{6}{|c|}{ Panel A. The Sure-Small-Quantity Block } \\
\hline $\begin{array}{l}\text { Quantity } \\
\text { (in Millions of Barrels) }\end{array}$ & Probability & & $\sigma=15 \%$ & $\sigma=22 \%$ & $\sigma=\mathbf{3 0} \%$ \\
\hline 100 & 0 & & 0.000 & 0.000 & 0.000 \\
\hline 90 & 0 & & 0.000 & 0.000 & 0.000 \\
\hline 80 & $3 \%$ & & 1.274 & 1.314 & 1.412 \\
\hline 70 & $7 \%$ & & 2.590 & 2.690 & 2.887 \\
\hline 60 & $10 \%$ & & 3.183 & 3.333 & 3.599 \\
\hline 50 & $13 \%$ & & 3.011 & 3.211 & 3.484 \\
\hline 40 & $14 \%$ & & 2.334 & 2.503 & 2.985 \\
\hline 30 & $15 \%$ & & 1.088 & 1.469 & 1.936 \\
\hline 20 & $16 \%$ & & 0.184 & 0.378 & 0.641 \\
\hline 10 & $18 \%$ & & 0.000 & 0.025 & 0.078 \\
\hline Cumulative & $96 \%$ & Value at $\mathrm{t}=3$ & 13.664 & 14.923 & 17.024 \\
\hline \multicolumn{3}{|c|}{ Option to Invest in Exploration at $\mathrm{t}=0$} & 2.872 & 3.858 & 5.504 \\
\hline \multicolumn{3}{|c|}{ NPV of the Exploration Phase at $t=0$} & -7.128 & -6.142 & -4.496 \\
\hline
\end{tabular}

Panel B. The Either-Dry-Well-or-Strike Block

\begin{tabular}{lcccc}
\hline $\begin{array}{l}\text { Quantity } \\
\text { (in Millions of Barrels) }\end{array}$ & Probability & $\sigma=\mathbf{1 5 \%}$ & $\sigma=\mathbf{2 2} \%$ & $\sigma=\mathbf{3 0} \%$ \\
\hline 100 & 0 & 0.000 & 0.000 & 0.000 \\
90 & $2 \%$ & 1.301 & 1.334 & 1.430 \\
80 & $4 \%$ & 2.175 & 2.243 & 2.410 \\
70 & $5 \%$ & 2.368 & 2.460 & 2.640 \\
60 & $11 \%$ & 4.482 & 4.692 & 5.067 \\
50 & $15 \%$ & 4.447 & 4.743 & 5.146 \\
40 & $18 \%$ & 3.842 & 4.120 & 4.913 \\
30 & $13 \%$ & 1.207 & 1.629 & 2.147 \\
20 & $7 \%$ & 0.103 & 0.212 & 0.359 \\
10 & $0 \%$ & 0.000 & 0.000 & 0.000 \\
Cumulative & $75 \%$ & 19.924 & 21.432 & 24.114 \\
Option to Invest in Exploration at t = & Value at t $=3$ & 6.076 & 6.999 & 8.641 \\
NPV of the Exploration Phase at t $=0$ & -3.924 & -3.001 & -1.359 \\
\hline
\end{tabular}

\section{Major Insights and Conclusions}

I presented a stage-by stage valuation of the development of an oil field concession block on the Dutch Continental Shelf. The experience gained from this actual implementation provides various insights regarding 1) the advantages and limitations of the option pricing methodology (OPM), 2) the factors that affect offshore decisions, and 3) adopting and implementing of the OPM in practice.

\section{A. Advantages and Limitations of the Option Pricing Methodology}

For the practical application of the OPM, it is important to assess both the advantages and 
Table 3. Valuation Results (in Millions of Dollars) (Continued)

\begin{tabular}{|c|c|c|c|c|c|}
\hline \multicolumn{6}{|c|}{ Panel C. The Speculative Block } \\
\hline $\begin{array}{l}\text { Quantity } \\
\text { (in Millions of Barrels) }\end{array}$ & Probability & & $\sigma=15 \%$ & $\sigma=22 \%$ & $\sigma=\mathbf{3 0} \%$ \\
\hline 100 & $5 \%$ & & 5.379 & 5.481 & 5.813 \\
\hline 90 & $6 \%$ & & 5.226 & 5.359 & 5.746 \\
\hline 80 & $8 \%$ & & 5.826 & 6.009 & 6.456 \\
\hline 70 & $8 \%$ & & 5.074 & 5.271 & 5.657 \\
\hline 60 & $8 \%$ & & 4.365 & 4.571 & 4.936 \\
\hline 50 & $8 \%$ & & 3.177 & 3.388 & 3.676 \\
\hline 40 & $5 \%$ & & 1.429 & 1.533 & 1.828 \\
\hline 30 & $4 \%$ & & 0.497 & 0.671 & 0.885 \\
\hline 20 & $2 \%$ & & 0.039 & 0.081 & 0.137 \\
\hline 10 & $2 \%$ & & 0.000 & 0.005 & 0.015 \\
\hline Cumulative & $56 \%$ & Value at $\mathrm{t}=3$ & 31.013 & 32.367 & 35.149 \\
\hline \multicolumn{3}{|c|}{ Option to Invest in Exploration at $\mathrm{t}=0$} & 9.605 & 10.225 & 11.496 \\
\hline \multicolumn{3}{|c|}{ NPV of the Exploration Phase at $t=0$} & -0.395 & 0.225 & 1.496 \\
\hline
\end{tabular}

limitations. The following points offer some insights:

1) Implementing the OPM and estimating the boundaries of its input parameters indicate a potential limitation in evaluating the worth of a concession. Very hard-to-estimate parameters, such as volatility in oil prices, sensitize the valuation results. Complicating the model with additional variables would not necessarily result in a better valuation or more accurate answers. For example, the model does not take into account currency exchange risk, tax carry-backs, and other such effects. With higher complexity, much of the intuition of viewing projects as real options may possibly be sacrificed. For this kind of applied research, more complex and very technical models would not add accuracy to the valuation results, and might lose other important features, such as accessibility of the methodology, tractability of the model, economic insights, and intuition.

2) Other staged-projects, such as R\&D or venture capital investment, ${ }^{4}$ can be valued using a similar stage-by-stage valuation. In this particular implementation, I used the concept of replicating future cash flows. The estimated value of a producing field was directly based on its relationship with oil futures. However, an implementation problem

${ }^{4}$ See for instance, Fried and Hisrich (1994) and Lerner (1994) for stages in venture capital investment decision-making and changes in (informational) uncertainties. arises due to the lack of observable quotes for longdated forward prices in the futures markets. Therefore, I estimated reasonable approximations for forward prices. An insufficient number of observable quotes of a related financial instrument is a general implementation problem of the OPM (e.g., in the valuation of R\&D programs). However, the methodology can still be applied if there exists a corresponding valuation for the underlying asset.

3) A major advantage of OPM over NPV scenario analysis is that it highlights an appropriate procedure for analyzing geological and oil price uncertainty and management's ability to react to it. In the analysis of the production phase, EBN used a good, fair, and bad scenario analysis. Each of these scenarios assumed a static managerial commitment to a certain investment plan, i.e., the analysis did not allow managerial flexibility. At first sight, the observed hurdle rate in this scenario (20\%) is exceedingly high. However, this can be explained by viewing the production phase as an option. Using this high hurdle rate, EBN requires a premium over the standard NPV and implicitly defers the project in periods of low prices. OPM represents a superior tool for capturing managerial flexibility.

\section{B. Factors that Affect Offshore Investment Decisions}

The OPM, when properly applied, can be useful 
in the project evaluation process. ${ }^{5}$ Quantitative techniques complement the strategic thinking process; they do not replace it. In order to believe a project's positive NPV, management has to think why a particular block is more valuable for this company than for its competitors. Typical value drivers in the offshore development include: whether the investment decision exploits an inherently attractive opportunity that is due to a lucky strike, (exclusive) geological information, or synergistic effects with other prospects; low investment cost because the block is near a company-owned pipeline or production facility; and finally, good timing due to high oil prices.

Thinking in terms of options impacts strategic planning in this particular area. The implementation of OPM illustrates that consideration of geological and oil price uncertainty is essential in the valuation of the exploration phase. The valuation results show that exploration investments in speculative blocks are more effective in resolving the inherent uncertainty, and hence are more valuable, than otherwise similar low-uncertainty blocks. This result, which may seem surprising at first glance, hinges on the fact that if the exploration phase fails, the enormous follow-on investment for the production phase need not be made. In other words, if the block turns out dry, then only the relatively small exploration investment is lost. On the other hand, more can be gained in a speculative block if it has exceptionally high values in the production phase.

The observed strategies of large oil companies support the idea that exploration investments are more effective, and hence more valuable, in uncertain areas. The reserves on the Dutch Continental Shelf are relatively small although their magnitude is certain due to extensive seismic and geological research. Recently, large exploration firms have decided to leave the Dutch Continental Shelf and explore unknown and uncertain areas in the Soviet Union and China, where there are believed to be opportunities for large discoveries. However, if oil prices were to rise substantially the smaller

\section{References}

Arthur Anderson \& Co.,1988, "The Netherlands Offshore and Oil Guide," AA7000, item 77.

${ }^{5}$ No methodology can capture all the factors that affect the investment decision, but for many investment selection criteria in corporate finance the problem is that they are too narrow. A firm's strategy arguably involves more than just making money for its shareholders: Firms also have a public responsibility in terms of employment, the environment, and so on. For example, there are large undeveloped fields that are not exploited because of the potential ecological damage to and more certain reserves at the Dutch Continental Shelf become commercial to develop.

\section{Mode of Calculation and Presentation}

Complicated methods are not easily adopted. Complex investment problems have to be simplified to make the analysis accessible for management. To make the model easier to understand, we used a discrete-time binomial process. Working backward from the production phase, decision-makers can trace the values and intuit from the model the relative magnitude of values in the different project phases. In addition, the discrete-time calculations also have an advantage in the tractability of the model to changes in taxes, geological distributions, and other parameters.

In order to present the model as a practical aid to corporate planners, we have developed appropriate user-friendly software with simulation capabilities. For this particular model, I used a Microsoft Excel spreadsheet. The total workbook (of $320 \mathrm{~kb}$ ) consists of three worksheets; an input sheet, a graphic sheet, and a calculation sheet (of FD columns by 170 rows). Given the diversity of investment problems inherent in the blocks, the spreadsheets can only provide a prototype for evaluating alternatives. Practitioners will need to adjust the spreadsheets to the particular geological expectations and requirements of their own prospects.

Clearly, from the increasing attention paid by corporations to option-pricing application and implementation issues, the practical use of real option analysis looks promising. Real option concepts and tools have been applied in internal (pilot) studies by leading firms in the oil industry, such as British Petroleum, Shell, and Amoco Netherlands Petroleum Company. Various other industries have analogous sequential investment programs and could apply real option concepts as illustrated in this paper. Real option applications have been used at Merck (pharmaceuticals) and are currently under consideration at Philips (consumer electronics) for evaluating product development programs.
Baldwin, C. and K. Clark, 1993, "Modularity in Real Options," Harvard Business School Working Paper.

Bjerksund, P. and S. Ekern, 1990, "Managing Investment Opportunities Under Price Uncertainty: from 'Last Chance' to 'Wait and See' Strategies," Financial Management (Autumn), 65-83.

an important natural area. It should be clear that value creation is a healthy goal and a good criterion from the financial management perspective, but other disciplines may also impose their own limitations. 
Brennan, M. and E. Schwartz, 1985a, "Evaluating Natural Resource Investments," Journal of Business (April), 135-157.

Brennan, M. and E. Schwartz, 1985b, "A New Approach to Evaluating Natural Resource Investments," Midland Corporate Finance Journal (Spring), 37-47.

Cox, J.C., S.A. Ross, and M. Rubinstein, 1979, “Option Pricing: A Simplified Approach," Journal of Financial Economics (September), 229-263.

Dixit, A. and R. Pindyck, 1994, Investment Under Uncertainty, Princeton, NJ, Princeton University Press.

Fried, V.H. and R. Hisrich, 1994, "Toward a Model of Venture Capital Investment Decision Making," Financial Management (Autumn), 28-37.

Ingersoll, J.E., Jr. and S.A. Ross, 1992, "Waiting to Invest: Investment and Uncertainty," Journal of Business (January), 1-30.

Kemna, A.G.Z., 1988, "Options in Real and Financial Markets," Erasmus University Doctoral Dissertation.

Kemna, A.G.Z., 1993, "Case Studies in Real Options," Financial Management (Autumn), 259-270.

Lerner, J., 1994, "The Syndication of Venture Capital Investments," Financial Management (Autumn), 16-27.

Majd, S. and R. Pindyck, 1987, "Time to Build, Option Value, and Investment Decisions," Journal of Financial Economics (March), 7-27.
Mason, S. and R.C. Merton, 1985, "The Role of Contingent Claims Analysis in Corporate Finance," in E.I. Altman and M. Subrahmanyan, Eds., Recent Advances in Corporate Finance, Homewood, IL, Irwin, 7-54.

Myers, S.C., 1987, "Finance Theory and Financial Strategy," Midland Corporate Finance Journal (Spring), 6-13.

Paddock, J., D. Siegel, and J. Smith, 1987, "Valuing Offshore Oil Properties with Option Pricing Models," Midland Corporate Finance Journal (Spring), 22-30.

Paddock, J., D. Siegel, and J. Smith, 1988, "Option Valuation of Claims on Real Assets: The Case of Offshore Petroleum Leases," Quarterly Journal of Economics (August), 479-508.

Shell, 1988, "Op Zoek naar Olie en Gas," Shell Rotterdam (April).

Smit, H.T.J., 1996, "Growth Options and Strategy Analysis," University of Amsterdam Doctoral Dissertation.

Smit, H.T.J. and L.A. Ankum, 1993, "A Real Option and Game Theoretic Approach to Corporate Investment Strategy under Competition," Financial Management (Autumn), 241-250.

Trigeorgis, L., 1986, "Valuing Real Investment Opportunities: An Options Approach to Strategic Capital Budgeting," Harvard University Doctoral Dissertation.

Trigeorgis, L., 1996, Real Options: Managerial Flexibility and Strategy in Resource Allocation, Cambridge, MA, MIT Press. 
Copyright of Financial Management (Financial Management Association ) is the property of Financial Management Association. The copyright in an individual article may be maintained by the author in certain cases. Content may not be copied or emailed to multiple sites or posted to a listserv without the copyright holder's express written permission. However, users may print, download, or email articles for individual use. 
Copyright of FM: The Journal of the Financial Management Association is the property of Financial Management Association and its content may not be copied or emailed to multiple sites or posted to a listserv without the copyright holder's express written permission. However, users may print, download, or email articles for individual use. 